
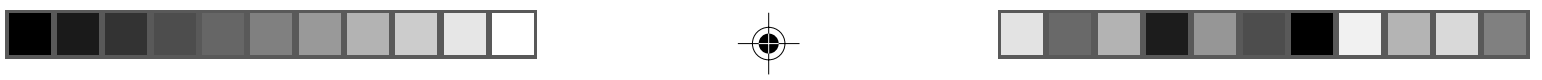

\title{
DER ER TO I ET MØDE \\ Perspektiver på kulturmødet fra psykiatrien
}

\section{KATRINE SCHEPELERN JOHANSEN}

Psykiatrien i Danmark er et af de steder, hvor mødet med den etniske anden de senere år har fået stadig stigende opmærksomhed. Dette kommer blandt andet til udtryk i et voksende antal kurser om transkulturel psykiatri og i oprettelsen af Videnscenter for Transkulturel Psykiatri i 2002. Ofte bliver dette møde i psykiatrien formuleret som et kulturmøde, men fokus er stort set kun på de etniske patienter og disses kultur samt de problemer, som personalet oplever i arbejdet med denne patientgruppe. Den stigende opmærksomhed i psykiatrien er blandt andet begrundet i den $\emptyset$ gede tilstedeværelse af patienter med anden etnisk baggrund end dansk, men den er ikke blevet fulgt af nogen systematisk ændring, tilpasning eller målretning af pleje- og behandlingstilbud. Man har søgt at behandle disse patienter inden for de eksisterende rammer, suppleret af mere eller mindre systematisk brug af tolke til de patienter, hvor den sproglige kommunikation er meget vanskelig. Den eneste form for særtilbud er ambulante behandlingstilbud til traumatiserede flygtninge. Det er derfor i den almindelige psykiatri - af feltet selv kaldet almenpsykiatrien - at behandlingen af disse patienter foregår, og det er her, kulturmødet foregår. Psykiatrien, som jeg beskæftiger mig med her, er det behandlingsfællesskab, der findes i praksis - selvfølgelig først og fremmest de steder, jeg har indsamlet empiri, men rækkende ud over disse konkrete steder til behandlingspsykiatrien generelt i Danmark.

I denne artikel vil jeg vise, hvordan psykiatrien selv er central for at forstå det kulturmøde, der finder sted, idet psykiatrien er medskaber af den konkrete udformning, som kulturmødet får i praksis. ${ }^{1}$ Antropologen Ann Jordan har skrevet om arbejdsfællesskaber som kulturelle fællesskaber (1994). En af hendes centrale pointer er, at man ikke skal komme til at gøre den fejl, som tidligere tiders antropologer gjorde, nemlig at anskue det kulturelle fællesskab, man arbejdede med, som afgrænsede enheder. Man skal i sin analyse være opmærksom på den kulturelle åbenhed og rettethed mod omverdenen. Dette er også en central pointe i forhold 

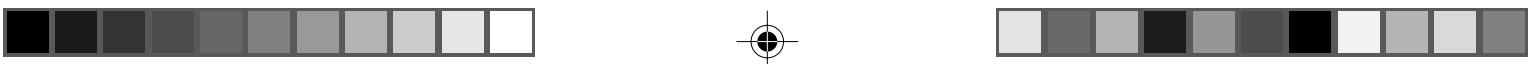

til de psykiatriske afdelinger, der selvfølgelig heller ikke udgør afgrænsede enheder i forhold til det omgivende hospital, samfund eller kultur. Der sker påvirkninger og interaktion, når patienter indlægges og udskrives, når der besluttes ny politik på hospitalet, eller når psykiatriaftaler omdefinerer psykiatriens rolle og ressourcer. Men alle disse påvirkninger og ændringer tillægges betydning, forstås og omfortolkes i det konkrete arbejdsfællesskab, som den enkelte afdeling udgør. Det er vigtigt her at understrege, at jeg $i$ en artikel som denne ikke har mulighed for at give en udtømmende præsentation af psykiatriens kultur, og spørgsmålet er, om dette i det hele taget er muligt. Denne artikel vil undersøge den del af den psykiatriske betydningsproduktion og praksis - den kultur - som knytter sig til den måde, som patienter med anden etnisk baggrund end dansk bliver forstået på.

Argumentet falder i to dele. For det første et generelt argument, der handler om, at set i lyset af et moderne antropologisk kulturbegreb er begge parter i et kulturmøde kulturbærere og påvirker derfor det konkrete møde. Anden del knytter denne argumentation specifikt til psykiatrien og viser, hvordan kultur ofte bliver knyttet til vanskelige patienter. I denne proces er der tale om to forskellige forhold. For det første er der tale om, at hvis patienter, der bliver opfattet som vanskelige, har en anden etnisk baggrund end dansk, så bliver denne baggrund en mulig forklaring på den vanskelige relation. Patienter med en anden etnisk baggrund, som ikke opfattes som vanskelige, bliver typisk ikke beskrevet som etniske eller kulturelle. ${ }^{2}$ Jeg analyserer dette fænomen ved at se disse patienter i forhold til den behandling, der praktiseres på de psykiatriske afdelinger, og viser, hvordan de udfordrer afdelingens behandlingstilbud. Anden del af processen handler om den måde, hvorpå psykiatrien opfatter relationen mellem psykisk sygdom og kultur. Her viser jeg, at psykiatriens opfattelse af denne relation er med til at fastholde patienten med anden etnisk baggrund end dansk som en vanskelig patient.

Konklusionen er en opsummering af argumentet og påpeger, at ønsker man at forstå det kulturmøde, der finder sted i psykiatrien, så kan man ikke nøjes med et fokus på den etniske patients kultur. Man bliver også nødt til at have den anden del - psykiatrien - med, da psykiatrien spiller en stor rolle for, hvordan den etniske patient bliver opfattet.

\section{Feltarbejdet}

Det empiriske materiale, som denne artikel er baseret på, stammer fra mit ph.d.projekt, hvor jeg unders $\emptyset$ gte, hvordan psykiatrisk personale forstod og arbejdede med den anderledes kulturelle baggrund hos patienter med en anden etnisk baggrund end dansk. Dette feltarbejde varede i alt 13 måneder og foregik på retspsykiatrisk afdeling på Sct. Hans Hospital, på et lukket sengeafsnit på voksen- 

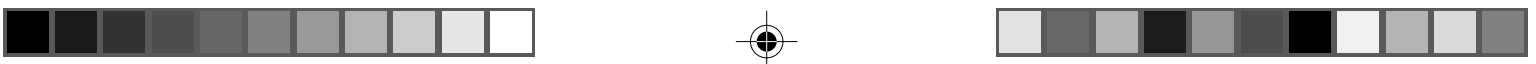

psykiatrisk afdeling på Bispebjerg Hospital og på Retspsykiatrisk Klinik i København. Empirien fra disse tre steder vil her blive præsenteret under ét af hensyn til at kunne anonymisere patienter og personale.

Årsagen til at studiet blev udført i retspsykiatrien og på et lukket sengeafsnit var, at det var her, man fandt den største andel af patienter med en anden etnisk baggrund end dansk (Kramp \& Gabrielsen 2001; Barfoed 1996). Det var min antagelse under planlægningen af studiet, at jo flere patienter med en anden etnisk baggrund end dansk der var til stede på en afdeling eller et sengeafsnit, i jo højere grad ville det være nødvendigt for personalet at reflektere over, hvordan disse patienter skulle behandles. De patienter, som på den ene eller anden måde blev en del af studiet, havde stort set alle en skizofrenidiagnose. Projektet undersøgte følgende forskningsspørgsmål: I hvilke situationer opfatter personalet kultur som et relevant emne? Hvordan taler personalet om disse patienter? Hvem bliver opfattet som værende med anden etnisk baggrund end dansk? Bliver disse patienter på nogen måde behandlet anderledes? Opfatter personalet dem som anderledes? Oplever personalet, at de mangler redskaber til at arbejde med denne patientgruppe? Samtidig med at jeg undersøgte disse spørgsmål, der fokuserede på den etniske patient, undersøgte jeg også den almindelige psykiatriske behandlingspraksis, da det var inden for denne praksis, at de etniske patienter blev behandlet. Metoderne, som jeg benyttede, var deltagerobservation i afdelingernes forskellige rum: opholdsstuer, personalekontor, ved behandlingskonferencer, til stuegangssamtaler m.m. samt interviews med patienter og personale. Jeg havde også journalindsigt i fem patienters journal på retspsykiatrisk afdeling.

\section{Tilgange til kultur}

Jeg vil i denne artikel anvende en pragmatisk definition af kulturbegrebet som de fælles normer, værdier og praksisser, der er knyttet til et givet socialt fællesskab (se Johansen 2006 for en nærmere udredning). En sådan definition kan dog få meget forskellige udtryk alt efter, hvordan den fortolkes. I det følgende vil jeg skelne mellem to kulturbegreber, et essentialistisk og et relationelt kulturbegreb. Disse to definitioner af kultur vil tjene to formål. For det første vil jeg bruge dem til at vise, at den kulturforståelse, som bruges inden for psykiatrien, i høj grad er essentialistisk. For det andet vil jeg vise, at ved at bruge en relationel kulturforståelse, så får man en anden - og mere anvendelig - tilgang til det kulturmøde, der finder sted.

I en del nyere antropologiske tekster om kultur skelner forfatterne mellem to kulturbegreber: Susan Wright skelner mellem et gammelt og et nyt kulturbegreb (1998:7). John Liep og Karen Fog Olwig laver et tilsvarende skel mellem et 
klassisk og et nyt kulturbegreb (1994:7-9). En af pointerne ved at fokusere på dette skel har været, at samtidig med at det gamle eller klassiske kulturbegreb har mistet videnskabelig legitimitet $i$ antropologien, er denne kulturforståelse blevet spredt ud i andre dele af samfundet og blevet brugt til at definere kultur i andre sammenhænge, fx politisk. En anden karakteristik af et sådant skel findes hos Thomas Hylland Eriksen, der i mere poetiske vendinger beskriver et skel mellem kultur som en $\varnothing$ og kultur som et elektrisk spændingsfelt (1994). Selv om der er forskelle mellem definitionerne, er der også en høj grad af sammenfald. Den følgende gennemgang af de to kulturbegreber bygger på en sammenstilling af de fælles pointer hos de nævnte forfattere. Jeg har valgt at bruge begreberne 'essentialiseret' og 'relationelt' til at karakterisere de to kulturforståelser, dels fordi skellet gammelt/klassisk og nyt indikerer, at det gamle ikke længere bruges, hvilket er forkert, og dels fordi disse betegnelser sætter fokus ved vigtige egenskaber ved de to tilgange - og i forhold til den følgende diskussion understreger vigtige pointer.

I den essentialiserede kulturforståelse antager man ofte en sammenhæng mellem etnisk gruppe, kultur og territorium. Den danske kultur kan identificeres som bestående af bestemte kulturelle elementer - kulturens essens - og er knyttet til det danske territorium. Den territorielle tilknytning skyldes dels, at den danske etniske gruppe lever på dette territorium, og dels at territoriets specifikke beskaffenhed menes at have formende betydning for kulturen. Denne kulturforståelse trækker blandt andet på romantikkens opfattelse af kultur, folk og fædreland, som man finder i Europa i 1800-tallet, og som har afgørende betydning for konstruktionen af nationalstaterne (se også Hastrup 2004:23-7). Det betyder også, at det er muligt klart at afgrænse kultur - der kan simpelthen tegnes grænser rundt om de forskellige kulturelle grupper. Kultur er som sådan noget, man fødes til, og den tænkes som relativt stabil og upåvirkelig hos det enkelte individ. Kultur opfattes som grundlæggende ens hos alle medlemmer af den pågældende etniske gruppe, fordi den består af noget givet, som man enten har eller ikke har. Mennesker bliver derfor også bærere af deres kultur - det er noget, som de har med sig, ligegyldigt hvorhen i verden de færdes. Og endelig bliver kultur i denne tilgang adfærdsstyrende - det enkelte individ tænkes at handle på baggrund af sine kulturelle normer og værdier.

Ved det relationelle kulturbegreb tager man samme udgangspunkt: Kultur er den fælles betydning og praksis, som mennesker i en given social gruppe deler og skaber sammen. Men i modsætning til det essentielle kulturbegreb understreges det, at disse normer og værdier m.m. er forskelligt fordelt og tillægges forskellig betydning og vægt inden for den pågældende gruppe. Dermed bliver kultur også langt mere heterogen, og det bliver centralt at se på, hvem der repræsenterer 

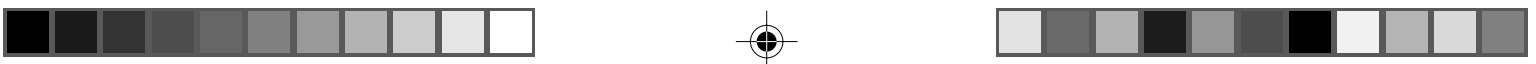

den pågældende kultur, i hvilken sammenhæng og med hvilket formål. Kultur er knyttet til sociale grupper frem for etniske. Den sociale gruppe kan være etnisk defineret, men kan lige så godt være politisk, arbejdsmæssigt eller seksuelt defineret. Dermed bliver det heller ikke muligt at trække skarpe grænser rundt om forskellige kulturer, da de løbende vil forandre sig i mødet. Frem for at kultur opfattes som en stabil ting, der er, er kultur noget, der skabes løbende, og dermed også forandrer sig over tid. Ofte sker denne kulturelle skabelse i relation til andre kulturelle fællesskaber. Det er i mødet med andre mennesker og deres kultur, at egne kulturelle normer, værdier og praksisser træder frem og bliver tillagt betydning (se også Hastrup 2004:10, 87-8). I denne tilgang opfattes mennesker som kulturbrugere og kulturskabere frem for kulturbærere. Det betyder også, at kultur bliver adfærdspåvirkende frem for adfærdsstyrende, da mennesker tillægges evnen til at handle både svarende til de kulturelle normer og i modstrid med dem.

De to kulturbegreber bør anskues som yderpunkter på et kontinuum, som de fleste kulturopfattelser kan placeres inden for med en vægtning mod enten den relationelle pol eller den essentielle pol. Det relationelle kulturbegreb repræsenterer i vid udstrækning resultatet af den gentænkning af kultur, som blandt andet fandt sted under det postmoderne brud i antropologien i 1980'erne (Hastrup 2004). Det relationelle kulturbegreb er dog ikke enerådende inden for antropologiens kulturdefinition; mere essentielle definitioner kan stadig findes (se fx Sahlins 1999).

\section{Kultur i psykiatrien}

Der skal være 'etnisk aften' på et afsnit. En tyrkisk patient skal lave tyrkisk mad, der skal spilles tyrkisk musik, og der skal ses en tyrkisk film om aftenen. Det er patienten selv og afsnittets ergoterapeut, der står for planlægning, madlavning, udsmykning m.m. Ifølge ergoterapeuten er det en god måde at skabe åbenhed og tolerance på blandt patienterne på afsnittet. Patienten er gået meget op i planlægningen og har været meget glad for den opmærksomhed, som afsnittets personale har vist ham. Han er dog lidt usikker på, om de øvrige patienter - særligt de danske, men også en kurdisk patient - vil synes om arrangementet. Han bruger en stor del af eftermiddagen på at ringe til sin tante, der bor i Danmark, for at spørge hende til råds om madlavningen, så den kan blive 'rigtig', da han ikke selv har den store erfaring med at lave mad. Foranlediget af disse forberedelser fortæller en anden - irakisk - patient om sine erfaringer med etniske aftener: 'Og så ville de have mig til at lave irakisk mad. Jeg har aldrig lavet mad, og da slet ikke irakisk. Hvis de så havde spurgt mig, om jeg ville lave lasagne eller burgere, det er jeg god til. ${ }^{3}$

Jeg har interviewaftaler med to kvindelige personalemedlemmer på det samme sengeafsnit i en aftenvagt. Den første fortæller, at hun synes, at hun tit har 

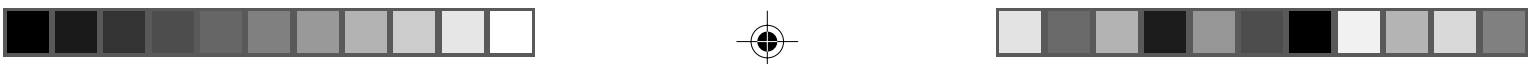

problemer med muslimske patienter - mændene gør ikke de ting, hun beder dem om at gøre. 'Det er på grund af deres kultur,' fortæller hun, 'der skal mænd ikke rette sig efter kvinder.' Senere samme aften i interviewet med det andet personalemedlem spørger jeg hende, om hun har problemer med muslimske mænd, der ikke gør, som hun beder dem om. 'Nej,' siger hun, 'det har jeg aldrig. Det er deres kultur at være høflige.'

Et tredje eksempel er fra en behandlingskonference, hvor man diskuterede en patient med skizofreni. Personalet var enig om hans diagnose og behandling, men der var til gengæld en del diskussion om hans adfærd, som personalet syntes var problematisk. Patienten var muslim og havde meddelt sin kontaktperson, at det var normalt for muslimer at være oppe hele natten for at bede, og at de derfor ikke skulle sende ham i seng. Personalet var meget i tvivl om, hvorvidt dette var rigtigt, om patienten brugte det som en undskyldning for at ligge og se fjernsyn hele natten på værelset, eller om det var et sygt fænomen - skizofrene patienter har ofte svært ved at sove og får tit vendt om på dag og nat. Samme patient røg ofte på sit værelse, hvilket ikke var tilladt på afsnittet. Han blev ofte korrigeret i dette og fik at vide, at det måtte han ikke, hvilket dog ikke forhindrede ham $i$ at fortsætte med at ryge der. Personalet diskuterede ofte, om det skyldtes, at han ikke respekterede de kvindelige personalemedlemmer, der tilretteviste ham.

Disse eksempler viser for det første, hvordan kultur i psykiatrien ofte bliver italesat som et essentialistisk kulturbegreb - som noget, den etniske patient har, som styrer hans adfærd, og som er problematisk i forhold til de psykiatriske afdelinger. Kultur bliver næsten udelukkende diskuteret i forhold til patienter med anden etnisk baggrund end dansk. Ofte bliver disse patienters fremmede kultur opfattet som problematisk, da de menes at have nogle normer og værdier, der ikke passer ind i forhold til de psykiatriske afdelinger og - i et større perspektiv - det danske samfund. For personalet bliver de psykiatriske afdelinger en direkte forlængelse af det omliggende samfund, og man oplever, at de værdier, som i samfundet generelt bliver beskrevet som danske, også eksisterer på afdelingerne. Et eksempel på en sådan værdi er ligestilling mellem kønnene (se Jacobsen \& Johansen 2002).

Selv om man kan sige, at denne opfattelse blandt personalet - at patienternes kultur ikke passer ind i det danske samfund - implicerer, at der også er kultur i det danske samfund, fører dette ikke til nogen yderligere opmærksomhed på, hvad denne danske kultur har af betydning for mødet med patienter med anden etnisk baggrund end dansk. Den danske kultur bliver opfattet som neutral og korrekt på de psykiatriske afdelinger såvel som i det danske samfund, netop fordi der antages at være en naturlig sammenhæng mellem Danmark og dansk kultur (se ovenfor), og fordi personalet opfatter de psykiatriske afdelinger som en naturlig del af det danske samfund. Det er de andres kultur, der er problemet. Med denne opfattelse af kultur ligner psykiatrien andre dele af det danske 

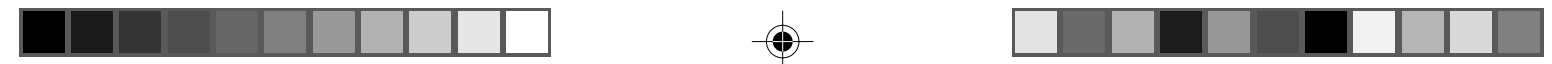

velfærdssystem, hvor andre antropologer har dokumenteret, at kultur bliver forstået på tilsvarende måde (se fx Jöhncke 1995; Fischel 1992; Sampson 1996).

Ud over at illustrere det essentialistiske kulturbegreb i psykiatrien viser disse situationer også, hvordan de psykiatriske afdelinger i sig selv har en vis betydning for den måde, kultur kommer til udtryk på, fx ved at arrangere en etnisk aften eller ved at italesætte en problematisk relation som et muligt kulturelt problem. I det sidste tilfælde kunne man have valgt at fokusere på andre mulige forklaringer, fx patientens sygdom. Dette peger på, at det kan være relevant at kigge på psykiatrien selv som havende betydning for, hvordan de etniske patienters kultur bliver forstået og omtalt. Med den analytiske terminologi, som jeg har valgt i denne artikel, viser eksemplerne, at det er relevant at kigge på psykiatrien som et kulturelt system, der i mødet med andre kulturer konstituerer disse andre på en særlig måde.

Med introduktionen af kultur som et mere åbent og fleksibelt system fulgte også en erkendelse af, at kultur kan være knyttet til andre sociale grupper end etniske grupper (Hastrup 2004). Andre sociale grupper, fx arbejdsfællesskaber, politiske fællesskaber og seksuelle fællesskaber, kan også være bærere af en fælles kultur, der kan analyseres ud fra de samme principper, som tidligere havde været forbeholdt etniske grupper. Det relationelle aspekt ved denne nye kulturforståelse peger på, at det er i mødet mellem forskellige sociale grupper, at de kulturelle særtræk skabes.

I mit arbejde med de psykiatriske afdelinger valgte jeg at anskue dem som kulturelle fællesskaber. Det betyder, at det er muligt at undersøge og analysere den betydningsproduktion og de praksisser, som man kan finde i disse sociale fællesskaber. De dominerende aktører i disse kulturelle fællesskaber er det psykiatriske personale (se også Barrett 1996). Det er dem, der fastsætter reglerne for, hvad man må og ikke må på afdelingerne; dem, der bestemmer, hvad der er korrekt adfærd, og hvad der er forkert adfærd. Og det er først og fremmest personalet, der optræder som en samlet gruppe, i modsætning til patienterne, der som regel optræder som enkeltindivider, og som ofte ikke har noget $\emptyset$ nske om at deltage i et fællesskab med de øvrige patienter. Det betyder ikke, at patienterne ikke er vigtige bidragydere til den kulturelle betydningsproduktion, der foregår, men de er det som individer, som den dominerende sociale gruppe (personalet) agerer i forhold til. Patienterne udvikler ofte ikke kulturelle fællesskaber, dels fordi mange af dem er for syge til at deltage i fællesskaber, dels fordi de ikke finder patientidentiteten attraktiv, og dels fordi de fleste af dem kun vil være til stede på afdelingen i kortere perioder. 


\section{E tniske patienter som vanskelige patienter i psykiatrien}

Patienter, der af psykiatrisk personale bliver omtalt som etniske eller kulturelle patienter, har som regel et eller flere karakteristika, som kan identificeres som etniske. Det kan være, at de har et meget anderledes klingende navn, noget særligt tøj, anderledes religiøse praksisser eller taler dansk med accent eller slet ikke. Det er dog ikke sådan, at besidder man et eller flere af disse karakteristika, så bliver man automatisk opfattet som havende anden etnisk baggrund end dansk. Denne karakteristik er som regel forbeholdt patienter, som man på en eller anden måde oplever som vanskelige. Det kan fx være, fordi man har svært ved at etablere en behandlingsrelation ${ }^{4}$ til patienten, fordi patienten bryder de aftaler, man laver, eller fordi man har vanskeligt ved at kommunikere med dem. Deres etniske baggrund bliver dermed en mulig forklaring på, hvorfor man oplever denne vanskelighed. Det er her relevant at nævne, at patienter med etnisk dansk baggrund også kan være vanskelige. I forhold til dem findes der andre forklaringer på, hvorfor behandling og relation er vanskelig. Det kan fx være på grund af deres diagnose, hvis de har en personlighedsforstyrrelse eller på grund af et stofmisbrug, hvis de har et sådan, eller adfærdsproblemer, hvis man ikke kan finde andre forklaringer.

Nedenfor præsenteres to patienter, som personalet opfattede som vanskelige, og hvor deres anden etniske baggrund end dansk blev opfattet som forklaringen på vanskelighederne. Eksemplerne er min sammenskrivning af en masse forskelligt materiale omkring disse patienter: Hvordan der blev talt om dem på to behandlingskonferencer, rapport ved vagtskifte, i dagligdagen og ved interviews med forskellige personalemedlemmer:

\footnotetext{
Mohammed var en mand i slutningen af 20'erne, som var født i Danmark af tyrkiske forældre. Han havde en skizofrenidiagnose, men personalet diskuterede, om han ikke snarere havde en personlighedsforstyrrelse, ${ }^{5}$ og om det var den, der var årsagen til hans afvigende adfærd. Derudover røg han meget hash, når han havde mulighed for det.

Han stak ofte af fra afdelingen, han var ikke interesseret $i$ behandling eller $i$ at skabe en behandlingsalliance med personalet. Personalet var i tvivl om, hvem han egentlig var, hvad han gerne ville, hvad han havde af planer for fremtiden, hvordan han kunne blive hjulpet, hvordan han kunne blive overbevist om, at personalet gerne ville hjælpe ham. Han var, kort sagt, en vanskelig patient. Han blev hyppigt flyttet mellem de forskellige afsnit og mellem de forskellige psykiatriske afdelinger på hospitalet. Denne flytten frem og tilbage tjente et officielt og et uofficielt formål. På den ene side blev han flyttet til andre afsnit eller afdelinger, hvor man mente, at han kunne få et bedre tilbud. På den anden side slap man også af med ham, når personalet var kørt træt.
} 

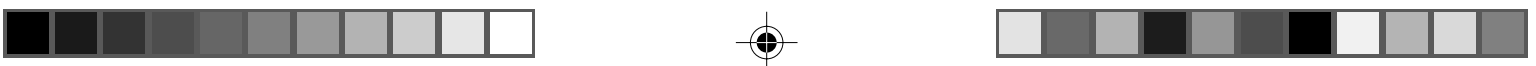

Blandt personalet blev det ofte diskuteret, om det var hans anderledes kulturelle baggrund, der var problemet. De havde svært ved at beskrive præcist, hvilken kulturel baggrund og hvordan den var problematisk, men denne følelse af ikke at kunne nå ham og ikke kunne behandle ham blev ofte formuleret som havende med hans kultur at gøre.

En anden patient, Ali, var flygtning fra Afghanistan. Også han blev af personalet opfattet som vanskelig. Ali var heller ikke interesseret $i$ at have en alliance med personalet. Han isolerede sig, deltog ikke i nogen fælles aktiviteter på afsnittet og syntes ikke at være interesseret i noget. Der var også nogen usikkerhed omkring hans diagnose. Var han rigtig skizofren, var der en organisk årsag til hans adfærd, var han dårligt begavet eller skyldtes det en dårlig skolegang i hans oprindelsesland? ${ }^{6}$

Men med Ali var der yderligere det problem, at han ikke kunne tale hverken dansk eller engelsk. Det var svært at finde en ordentlig tolk på grund af hans dialekt, og de tolke, som det lykkedes at lokalisere, var ikke særlig gode. Enten talte de ikke godt nok dansk, eller også var personalet usikre på, om de oversatte alt, hvad de sagde til patienten, og alt hvad patienten sagde til dem. Ud over sproget blev kultur også nævnt som et problem i forhold til Ali. Var det på grund af hans kultur, at han ikke udførte de tildelte opgaver på afsnittet og ikke talte med personalet? Som en strategi til at finde ud af noget mere om hans kultur havde hans kontaktpersoner indsamlet en hel mappe med informationer om Afghanistan. Deres håb var, at de derved ville være i stand til at vurdere, hvad i hans adfærd, der var kultur, og hvad der var symptomer på hans sygdom. Dette virkede dog ikke for dem; de blev ikke bedre til at skelne, og de lærte ikke Ali bedre at kende. De fandt det svært at relatere de generelle oplysninger om Afghanistan til Ali og hans isolerende adfærd på den psykiatriske afdeling.

Eksemplerne med Muhammed og Ali viser endnu en gang, at det ofte er et essentielt kulturbegreb, der anvendes på de psykiatriske afsnit, når personalet refererer til patienters kultur. I forhold til begge patienter mener personalet, at objektiv kulturel viden om deres kulturelle baggrund vil hjælpe dem til at forstå. I Alis tilfælde illustreres det rent fysisk af den mappe med kulturelle data, som personalet samler fra en række forskellige kilder, men ikke fra Ali. Samtidig gives der ingen plads til en mere relationel kulturforståelse og opmærksomhed omkring, hvorvidt nogle af de karakteristika, der blev opfattet som kulturelle, kunne skyldes det rum, der blev skabt for disse patienter på afdelingerne.

Noget andet, som var interessant ved Mohammed og Alis eksempler, var, at der på samme afdeling var andre patienter fra disse lande, hvor kultur ikke blev diskuteret eller overvejet. I modsætning til Mohammed og Ali blev disse patienter opfattet som nemme at arbejde med. Enten var deres sygdom så tydelig, at ingen kunne være i tvivl om deres diagnose eller deres behov for behandling og hjælp. Eller det var lykkedes dem at forme en behandlingsalliance med personalet $-\mathrm{i}$ form af en fælles forståelse af, hvad deres primære problemer var, eller at de 
behøvede den form for behandling og hjælp, som personalet kunne give. De kunne med andre ord rummes inden for rammerne af afsnittenes behandlingstilbud. Det vil sige, at kultur blev bragt i spil i forhold til Muhammed og Ali, fordi personalet syntes, at de var vanskelige at have med at gøre. Deres anderledes kulturelle baggrund blev dermed en mulig forklaring på den vanskelighed, som personalet oplevede i forhold til disse patienters behandling. De følgende to afsnit vil analysere, hvordan forskellige elementer ved psykiatriens egen kultur er med til at konstituere disse to patienter som vanskelige.

\section{Afdelingernes behandlingstilbud}

Én måde at forstå, hvorfor patienter med anden etnisk baggrund end dansk bliver opfattet som vanskelige, er at kigge på den position, de indtager i forhold til de behandlingstilbud, som de psykiatriske afdelinger tilbyder. Antropologerne Jöhncke, Svendsen og Whyte foreslår, at man ser på forskellig slags behandling som sociale teknologier.

Problemer formes af allerede forestillede løsningsmodeller; for at blive opfattet som relevante må problemerne først underkastes ganske bestemte forståelser og beskrivelser for at komme inden for menneskelig rækkevidde som noget, der kan løses eller i det mindste lettes (Jöhncke, Svendsen \& Whyte 2004:385).

I denne proces med at definere problemer defineres også målgruppen for løsninger samt dem, der falder uden for disse løsninger:

Det vil sige, at sociale teknologier skaber bestemte målgrupper, særlige kategorier af individer eller grupper, der er karakteriseret ved at besidde det problem, som løsningen kan indkredse, fastholde og håndtere (Jöhncke, Svendsen \& Whyte 2004:392).

Dermed er der også mennesker, der ikke tilhører den relevante målgruppe (se også Järvinen \& Mik-Meyer 2003). Anvendes dette perspektiv på de psykiatriske afdelinger, kan man se, at det primære behandlingstiltag er en medicinsk behandling med antipsykotisk og beroligende medicin samt et struktureret miljø, dvs. klare regler for adfærd, dagsprogram, kontakt med omverdenen samt begrænsning af diverse stimuli. Disse tiltag menes at have en god effekt på patienter, der er psykotiske skizofrene og maniske ${ }^{7}$ (patienter med andre former for psykiske lidelser bliver selvfølgelig tilbudt andre former for behandling). På disse afdelinger fremhæver personalet som regel, at de patienter, som de bedst kan lide at arbejde med, er patienter med en tydelig skizofren diagnose - af noget personale kaldet „de rigtig dejlig skizofrene“. Tiltagene er til gengæld mindre egnede til at behandle 

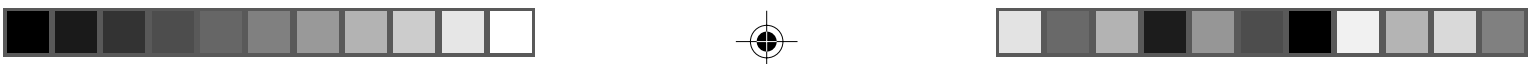

personlighedsafvigelser, hashmisbrug m.m. Disse patienter udfordrer dermed den sociale teknologi, som afdelingerne anvender.

I optikken fra den sociale teknologi er kategorien 'patienter med anden etnisk baggrund end dansk' en kategorisering af patienter, der ikke passer til teknologien. Det bliver en beskrivelse af patienter, der har nogle karakteristika, der besværliggør eller forhindrer den behandling/teknologi, som personalet tilbyder og anvender. Nogle personalemedlemmer beskriver, hvordan de bruger ekstra tid på patienter med anden etnisk baggrund end dansk, hvordan de søger at give disse patienter en behandling, der er tilpasset deres særlige baggrund. Men i mange af disse forsøg ligger der samtidig et forbehold om, at det ikke er sikkert, at man lykkes nær så godt med disse patienter, netop fordi de er etniske. I kategoriseringen 'patienter med anden etnisk baggrund end dansk' ligger der dermed en potentiel mulighed for at forklare, hvorfor et patientforløb ikke lykkedes optimalt.

Den hollandske antropolog Rob van Dijk beskriver, hvordan kultur i Holland er blevet en forklaring på, at sundhedsarbejdet med etniske minoriteter ikke lykkes (1998). At der er en, om ikke andet så implicit, forståelse af dette forhold i felten, kan ses i det svar, jeg fik fra en psykiatrisk overlæge. Jeg spurgte ham, om det betød noget, når halvdelen af hans patienter havde en anden etnisk baggrund end dansk: „Vi forsøger at give alle samme gode behandling. Eller i hvert fald den samme behandling - så må andre vurdere, om den er god." Oplevelsen af denne patientgruppe som noget særligt besværligt eller anderledes bliver også bekræftet i fx undervisningsforløb om den etniske eller muslimske patient på hospitalerne - og i projekter som mit, der sætter fokus på denne patientgruppe. Afdelingernes behandlingstilbud, deres sociale teknologier, er med til at definere nogle patienter som rigtige patienter, der hører til, og andre patienter som nogen, der er vanskelige, som ikke passer ind, og som dermed udfordrer disse teknologier.

Man kan påpege, at psykiatrien mangler at få inkorporeret tilgange i deres sociale teknologi, der gør det muligt at behandle de patienter, som nu bliver opfattet som havende en anden etnisk baggrund end dansk. Med reference tilbage til Mohammed og Ali kan man pege på, at dette blandt andet bør indeholde en mere systematisk og hyppig brug af tolk, en opmærksomhed omkring, hvordan man kan etablere en behandlingsalliance, når de almindelige tilgange og teknikker ikke virker, hvilken rolle personalets egne kategoriseringer af patienterne spiller, og en mere relationel kulturopfattelse, hvor patienternes egne kulturelle normer og værdier kommer til at tegne billedet af deres kultur frem for essentialistisk viden om kulturer generelt.

Der er dog også et andet forhold, der spiller ind for at forstå, hvordan etnicitet og vanskelighed spiller sammen, nemlig hvordan man i psykiatrien opfatter relationen mellem kultur og sygdom. Det følgende afsnit beskriver denne rela- 

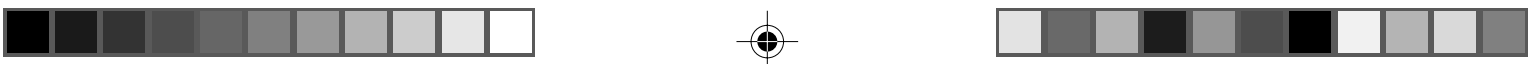

tion og viser, hvordan den er med til at fastholde de patienter, der er blevet kategoriseret som etniske eller kulturelle, i en position som vanskelige.

\section{Relationen mellem kultur og sygdom}

I et interview med en psykiater spurgte jeg, hvordan hun mente, relationen mellem kultur og sygdom var. Hun svarede lidt forundret, at hun selvfølgelig delte det synspunkt, at kultur er patoplastisk, og at biologien er patogenetisk. Disse begreber, patoplastisk og patogenetisk, og denne forståelse genfinder man i megen psykiatrisk litteratur omkring dette forhold (se fx Kristensen \& Ali 2000; Nørregaard 2002), og de udgør som sådan psykiatriens officielle forståelse af dette forhold. Patogenetisk henviser til den egentlige årsag til sygdom, hvad der skaber den. Patoplastisk henviser til, hvordan sygdomsudtrykket bliver formet. I moderne psykiatri menes både skizofreni og affektive sygdomme at skyldes en biologisk sårbarhed, og dermed, at den egentlige årsag til sygdommen (patogenese) er biologisk (se Parnas 2000:350). Patoplastik har at gøre med den aktuelle manifestation af symptomer, fx hvad ens hallucinationer handler om, eller hvordan man kommunikerer oplevelsen af ikke at leve i den samme verden som andre mennesker (Littlewood \& Dein 2000:4-5).

I litteraturen findes der forskellige illustrative metaforer til at anskueliggøre denne relation. ${ }^{8}$ Psykiateren Christian Nørregaard skriver således: „En metafor herfor kunne være glasuren (dvs. det eksotiske syndrom), som dækker kagen (dvs. den egentlige sygdom, fx skizofreni)“(2002:204; parenteser i original). Det eksotiske syndrom er det kulturelle udtryk, som sygdommen får, og kultur bliver altså her lignet med glasur. Antropologen Roland Littlewood og hans kollega Simon Dein skriver:

... den stadig gældende model for psykisk sygdom [...] kan beskrives som lignende en russisk dukke: De essentielle biologiske determinanter, der specificerer en sygdom, er omringet af en serie forvirrende kulturelle og idiosynkratiske lag, som man bliver nødt til at fjerne i den diagnostiske proces for at afsløre den sande sygdom (Littlewood \& Dein 2000:6-7; min oversættelse, KJS).

Denne opfattelse af forholdet mellem kultur og psykisk sygdom er lige så gammel som interessen for psykiske sygdom i fremmede lande og eksotiske kulturer (Littlewood \& Dein 2000). I et af de første essays inden for dette område skrev den tyske psykiater Emil Kraepelin i 1904 - efter et besøg på Java:

... der er på nuværende tidspunkt ikke nogen overbevisende grund til at antage, at de indfødte på Java lider af nye og ukendte former for sindssygdomme [...] På den anden side, så undergår de sygdomme, som vi er bekendte med, forandringer på 

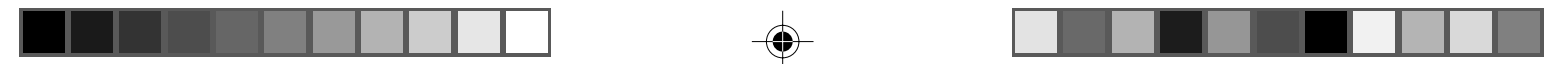

Java, som vi med nogen ret kan tilskrive patienternes racemæssige karakteristika. [...] Hvis racemæssige karakteristika bliver reflekteret $i$ en nations religion og traditioner, i dens spirituelle og kunstneriske præstationer, i dens politiske aktivitet og historiske udvikling, så må de også komme til udtryk i de psykiske sygdommes hyppigheden og kliniske udtryk (Kraepelin 2000:41; min oversættelse, KJS).

Selv om Kraepelin her bruger betegnelsen race om det fænomen, der adskiller de forskellige mennesker på jorden, er adskillelsen mellem den generelle sygdom og den racemæssige eller kulturelle formning af sygdommen også tydelig. Fra et medicinsk antropologisk synspunkt er dette skel mellem kultur og sygdom slående: Psykiateren mener, at noget af det, som patienten beretter om og oplever, er kultur, og andet er sygdom. Kultur bliver dermed noget, der forstyrrer billedet, og noget, der skal fjernes for at afsløre 'den sande sygdom' nedenunder (Littlewood $\&$ Dein 2000:8-9). Som en modsætning til dette er der mange eksempler fra den medicinske antropologi, der dokumenterer, hvordan kultur og sygdom er forbundet og påvirker hinanden. Nogle af de kendteste eksempler er fra Nancy ScheperHughes (2001) og Arthur Kleinman (Kleinman \& Kleinman 1985), der begge har beskrevet, hvordan forskellige kulturelle praksisser kan fremkalde psykisk sygdom, hvorfor de psykiatriske symptomer ikke kan forstås uden reference til de kulturelle fællesskaber, som de forekommer i. Antropologerne Steffen og Jessen har en tilsvarende konklusion: „Det er først, når sygdommen spejles i den sociale og kulturelle virkelighed, den optræder i, at et meningsfuldt mønster træder frem “ (2002:25).

Ud fra et antropologisk perspektiv er antagelsen om adskillelsen mellem kultur og psykisk sygdom således ikke valid. Det er interessant at bemærke, at selv om man i psykiatrien i princippet mener, at der er en 'rigtig' sygdom neden under kulturen, kan man i praksis have svært ved at blive enige om, hvad det er for en sygdom. Som et illustrativt eksempel på de problemer, som anvendelsen af denne model giver i praksis, vil jeg referere til den malaysiske sygdom 'amok'. Amok er en lidelse, hvor et menneske pludselig bliver meget aggressivt, løber omkring og råber og slår, ofte angriber andre mennesker voldsomt og er fuldstændig umuligt at få beroliget. Ofte ender et anfald med, at personen løber ud i skoven og ikke kommer tilbage. Fors $\emptyset \mathrm{g}$ på at finde frem til den underliggende sygdom har udmøntet sig i følgende liste af forslag: epilepsi, malaria, kroniske cerebrale infektioner, forgiftning, hashindtagelse, alkoholindtagelse, en primitiv udladningsreaktion (svarende til affektreaktioner hos psykopater), delirium, agiteret depression, mani, akutte angstreaktioner, akutte katastrofereaktioner, hysteri og frygt (Reisby 1985:605-6). Så selv om modellen med at skelne mellem en sygdomskerne og en omkringliggende kultur kan virke teoretisk fornuftig ud fra psykiatriens sygdomsforståelse, giver den i praksis store problemer. 

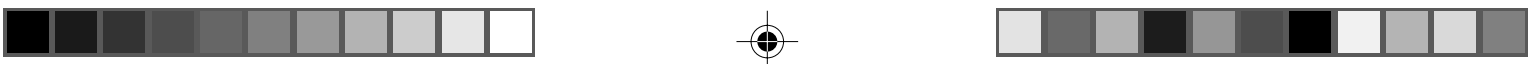

Tendensen mod, at kultur er noget, som kan og skal fjernes for at afdække den egentlige sygdom, har også nogle andre grundlæggende og problematiske konsekvenser. Et problem er, at den etniske patients udsagn om sygdom og liv kan blive opfattet som besværlige - kulturen forstyrrer billedet. Et andet problem er, at det er en opgave, som aldrig vil lykkes. Fordi kultur er en integreret del af næsten alle oplevelser af og udtryk for sygdom for patient og behandler såvel som for den menneskelig væren generelt, kan den ikke fjernes. Mennesker findes ikke uden kultur (Hastrup 2004). Men den psykiatriske forståelse af denne relation kan fange personalet $\mathrm{i}$ en fortsat kamp for at komme ned under kulturen, hvilket fastholder den etniske patient som en problempatient.

Hvis vi vender tilbage til Muhammed og Ali, så kan vi se, at personalets tilskrivning af kulturel anderledeshed blev en komplicerende faktor i nogle allerede komplicerede forløb. De to blev defineret som problematiske og deres kultur som en del af dette problem. På grund af personalets fors $\emptyset \mathrm{g}$ på at kunne adskille, hvad der er kultur, og hvad der er sygdom, blev personalet engageret $i$ et fortsat forsøg på at komme bag om eller ned under deres kultur. Dette ses fx i personalets fors $\emptyset \mathrm{g}$ på gennem deres mappe om Afghanistan at finde ud af, om det var Alis kultur eller hans sygdom, der gjorde, at han afviste kontakt. Da man ikke kan lave dette skel, så vil Muhammed og Ali sandsynligvis fortsætte deres karrierer som vanskelige patienter.

Den forståelse af behandling, som normalt er styrende for kontakten mellem patient og personale (behandlingsalliancen), er i forhold til disse patienter brudt sammen, og det er i personalets søgen efter noget andet, at kultur bliver bragt på banen. Kultur bliver som sådan en mulighed for at udtrykke et hul i den professionelle logik i faglige termer, og den bliver en metafor for et sammenbrud i den almindelige behandlingstilgang. Kultur, i den form og forståelse som anvendes i psykiatrien, synes dog ikke at forløse dette sammenbrud. Som eksemplerne ovenfor viser, bliver patienterne ikke hjulpet af, at kultur bliver bragt i spil.

I en artikel omkring aids-forskning i Afrika påpeger Packard og Epstein, at kultur bruges til at forklare det ellers uforklarlige smittemønster, som man finder i Afrika. De påpeger ligeledes, at der er en tendens til, at kultur, når det bruges på denne måde, bliver dekontekstualiseret. Man tager små kulturelle bidder og præsenterer som forklaring, men ignorerer den sociale, politiske, $\varnothing$ konomiske, historiske og kulturelle kontekst, som bidderne er taget fra (1991). Dette er helt parallelt til den måde, vi ser kultur blive brugt på inden for psykiatrien. Der er altså ikke tale om et særligt psykiatrisk fænomen, men tilsyneladende om en mere generel problematik i krydsfeltet mellem medicin og antropologi.

Ud fra et antropologisk perspektiv vil anbefalingen traditionelt være en integreret tilgang, hvor man undersøger samspillet mellem kultur og sygdom. Dette vil 

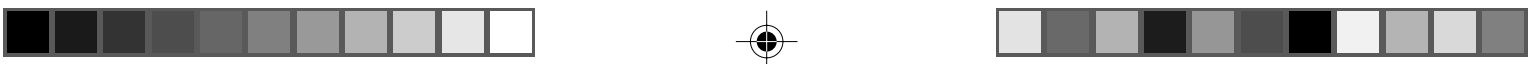

give personalet vigtige informationer omkring patienterne og deres oplevelse af den sygdom, som de lider af (se fx Kleinman 1977; Kleinman \& Kleinman 1985). Men i modsætning til denne antagelse om, at patienternes kulturelle bag-grund generelt spiller ind på det kliniske møde, viser min diskussion, at kultur ikke som sådan er et generelt forhold ved patienten med anden etnisk baggrund end dansk, men snarere er knyttet til et kompliceret samspil mellem sygdomsopfattelser, patientens identitet og den institutionelle ramme. Patienter, som er bedre tilpasset det psykiatriske behandlingstilbud, vækker ikke samme kulturelle undren på trods af samme etniske baggrund. Hos dem er der ikke så megen tvivl om sygdom og behandling.

Dermed bliver det tydeligt, at dette forhold ved psykiatriens egen kultur dvs. den betydning, som man på afdelingerne tillægger de etniske patienter og deres anderledes baggrund - er helt centralt for at forstå, hvordan et givent kulturmøde forløber. Bliver den etniske patient opfattet som en, der passer til psykiatrien, en, som man kan hjælpe, så bliver hans anderledes kulturelle baggrund ikke et problem; som regel vil han slet ikke blive beskrevet som en patient med anden etnisk baggrund end dansk. Modsat gælder det for en patient, som ikke ønsker eller formår at indpasse sig under psykiatriens rammer. Denne patient vil blive opfattet som vanskelig, og vedkommendes kultur vil blive en mulig forklaring på disse vanskeligheder.

Vender vi tilbage til kulturbegreberne fra første del af denne artikel, kan vi også se, at en anden dimension af dette problem er, at personalet primært anvender et essentialistisk kulturbegreb (rent fysisk manifesteret i Afghanistan-mappen), der dels fokuserer på kultur som noget givet, stabilt og fælles for hele etniske grupper, og som dels lukker af for en opmærksomhed omkring psykiatriens kultur og dennes betydning for mødet med den etniske patient.

\section{Konklusion}

Denne artikel har vist, at den betydning, som psykiatrisk personale tillægger patienter med anden etnisk baggrund end dansk, har en afgørende betydning for, hvordan mødet mellem disse patienter og det psykiatriske behandlingssystem spænder af. Diskussionen er dels blevet ført fra et kulturteoretisk synspunkt, hvor jeg har argumenteret for, at opfattes kultur som et relationelt fænomen, så bliver man nødt til at medtænke begge sider i et kulturmøde. Psykiatriens kultur spiller en vigtig rolle for den måde, hvorpå den etniske patients kultur bliver italesat og bragt i spil på de psykiatriske afdelinger.

I forhold til psykiatrien konkret har artiklen vist, hvordan patienters anderledes etniske baggrund bliver en mulig forklaring på en vanskelig relation mellem 
patienten og personalet. Denne vanskelighed kan findes på flere niveauer - dels i forhold til, om psykiatrien har behandlingstilbud, der kan rumme denne gruppe, og dels i forhold til, hvordan patienternes kultur og sygdom tænkes at spille sammen. Artiklen peger dermed på, at kulturmødet skal placeres i en kontekst for at kunne forstås. Psykiatrien er nemlig med til at bestemme, hvilke patienter der bliver opfattet som etniske eller kulturelle, og spiller dermed en central rolle i forhold til det kulturmøde, der finder sted på afdelingerne.

\section{Noter}

1. Denne artikel bygger på en række kapitler fra min ph.d.-afhandling (Johansen 2006), særligt kapitel 3, 6 og 8 .

2. I psykiatrien differentieres der ikke mellem etnicitet og kultur, og begge begreber bruges af personalet.

3. Sidste del af eksemplet optræder i Jacobsen og Johansen (2002:40).

4. En 'behandlingsrelation' er et psykiatrisk begreb, der bruges til at beskrive en relation mellem patient og personale, hvor patienten anerkender at være syg, og at personalets behandling kan hjælpe.

5. Skizofreni er en alvorligere sindssygdom end en personlighedsforstyrrelse. Der foregår en løbende diskussion inden for psykiatrien om, hvorvidt mennesker med en personlighedsforstyrrelse overhovedet hører til i psykiatrien, eller om de skal tilknyttes andre former for behandling, fx pædagogisk eller social behandling. Når personalet diskuterer, om en patients diagnose er skizofreni eller personlighedsforstyrrelse, er det også en diskussion om, hvorvidt patienten overhovedet hører til hos dem, og om vedkommende har et krav på at blive behandlet af dem.

6. I praksis er der et vist sammenfald mellem symptomerne på disse forskellige lidelser og problemer, der kan forklare disse overvejelser.

7. Skizofreni er en sindssygdom, hvor ens opfattelse af virkeligheden er ændret. Symptomer på sygdommen kan være hallucinationer, storhedsforestillinger og forfølgelsesforestillinger. Patienter kan have perioder, hvor disse symptomer er fraværende, og perioder, hvor de er til stede. Når symptomerne er til stede, siger man, at patienten er psykotisk. Patienter med mani er i et meget løftet stemningsleje, som regel overdrevent glade og positive, de har påfaldende meget energi og er ofte grænseløse i deres opfindsomhed, initiativ og kontakt med andre mennesker. I praksis kan disse to patientgrupper ligne hinanden, selv om det er to forskellige sygdomme, og der er en del lighedspunkter i behandlingen.

8. Der findes i psykiatrien også mere komplekse modeller vedrørende samspillet mellem sygdom og kultur (se fx Kirmayer 2004; Engel 1980). Det er dog sjældent, at det er disse modeller, der refereres til i praksis. 
Litteratur

Barfod, Anita

1996 Sindslidende indvandrere og flygtninge. Rapport over en undersøgelse om behandlingstilbud i Danmark. København: Socialt Udviklingscenter (SUS).

Barrett, Robert

1996 The Psychiatric Team and the Social Definition of Schizophrenia. Cambridge: Cambridge University Press.

Engel, George L.

1980 The Clinical Application of the Biopsychosocial Model. American Journal of Psychiatry 137(5):535-44.

Eriksen, Thomas Hylland

1994 Det tabte kulturelle øyrike. I: Thomas Hylland Eriksen: Kulturelle veikryss. Essays om kreolisering. Oslo: Universitetsforlaget.

Fischel, Lisa

1992 Kulturens klamme hånd: om mødet mellem flygtninge og de offentlige systemer i Danmark. I: Esther Fihl \& Jens Pinholt (red.): Livsformer og kultur. København: Akademisk Forlag.

Hastrup, Kirsten

2004 Kultur: Det fleksible fællesskab. Århus: Aarhus Universitetsforlag.

Jacobsen, Charlotte Bredahl \& Katrine Schepelern Johansen

2002 Kulturmøde i psykiatrien. Roskilde: Sct. Hans Hospital, H:S.

Johansen, Katrine Schepelern

2006 Kultur og psykiatri. En antropologi om transkulturel psykiatri på danske hospitaler. Ph.d.-rækken nr. 37. København: Institut for Antropologi.

Jordan, Ann T.

1994 Organizational Culture: The Anthropological Approach. NAPA Bulletin 14:3-16.

Järvinen, Margaretha \& Nanna Mik-Meyer

2003 At skabe en klient. Institutionelle identiteter i socialt arbejde. København: Hans Reitzels Forlag.

Jöhncke, Steffen

1995 Hvis kultur? Politik og praksis i indsatsen for hiv-smittede udlændinge i Danmark. København: HIV-Danmark.

Jöhncke, Steffen, Mette Nordahl Svendsen \& Susan Reynolds Whyte

2004 Løsningsmodeller. Sociale teknologier som antropologisk arbejdsfelt. I: Kirsten Hastrup (red.): Viden om verden. København: Hans Reitzels Forlag.

Kirmayer, Lawrence M.

2004 The Cultural Diversity of Healing: Meaning, Metaphor and Mechanism. British Medical Bulletin 69:33-48.

Kleinman, Arthur

1977 Depression, Somatization and the "New Cross-Cultural Psychiatry". Social Science and Medicine 11:3-12. 
Kleinman, Arthur \& Joan Kleinman

1985 Somatization. The Interconnections in Chinese Society among Culture,

Depressive Experience and the Meaning of Pain. I: Arthur Kleinman \& Byron

Good (eds.): Culture and Depression. Studies in the Anthropology and Cross-

Cultural Psychiatry of Affect and Disorder. Berkeley: University of California

Press.

Kraepelin, Emil

2000 [1904] Comparative Psychiatry. I: Roland Littlewood \& Simon Dein (eds.): Cultural Psychiatry and Medical Anthropology. An Introduction and Reader. London: The Athlone Press.

Kramp, Peter \& Gorm Gabrielsen

2001 Retspsykiatri i H:S - en spørgeskemaundersøgelse. København: Hovedstadens Sygehusfællesskab.

Kristensen, Majken \& Fatuma Ali

2000 Transkulturel psykiatri. I: Ralf Hemmingsen, Josef Parnas, Anette Gjerris, Per Kragh-Sørensen \& Niels Reisby (red.): Klinisk psykiatri. København: Munksgaard Danmark.

Liep, John \& Karen Fog Olwig

$1994 \quad$ Kulturel kompleksitet. I: John Liep \& Karen Fog Olwig (red.): Komplekse liv. Kulturel mangfoldighed i Danmark. København: Akademisk Forlag.

Littlewood, Roland \& Simon Dein

2000 Introduction. I: Roland Littlewood \& Simon Dein (eds.): Cultural Psychiatry and Medical Anthropology. An Introduction and Reader. London: The Athlone Press.

Nørregaard, Christian

2002 Kulturbundne syndromer, somatoforme tilstande, dissociation og angst. I:

Francisco Alberdi, Christian Nørregaard, Marianne Kastrup \& Majken

Kristensen (red.): Transkulturel psykiatri. København: Hans Reitzels Forlag.

Packard, Randall M. \& Paul Epstein

1991 Epidemiologists, Social Scientists, and the Structure of Medical Research on AIDS in Africa. Social Science and Medicine 33(7):771-94.

Parnas Josef

2000 Det skizofrene spektrum. I: Ralf Hemmingsen, Josef Parnas, Anette Gjerris, Per Kragh-Sørensen \& Niels Reisby (red.): Klinisk Psykiatri. København:

Munksgaard Danmark.

Reisby, Niels

1985 Transkulturel psykiatri (etnopsykiatri). I: Josef Welner, Niels Reisby, Villads Lunn, Ole Rafaelsen \& Fini Schulsinger (red.): Psykiatri - en tekstbog.

København: Foreningen af danske lægestuderendes forlag.

Sahlins, Marshall

1999 Two or Three Things that I Know about Culture. The Journal of the Royal Anthropological Institute 5(3):399-421.

Sampson, Steven

1996 Why do Bosnian Kids Piss on the Floor? Anthropology in Action 3(1):17-21.

Scheper-Hughes, Nancy

2001 Saints, Scholars, and Schizophrenics. Mental Illness in Rural Ireland. Berkeley: University of California Press. 
Steffen, Vibeke \& Hanne Jessen

$2002 \quad$ Kultur og sygdom - fra klassifikatorisk orden til kulturel kompleksitet. I:

Francisco Alberdi, Christian Nørregaard, Marianne Kastrup \& Majken

Kristensen (red.): Transkulturel psykiatri. København: Hans Reitzels Forlag.

van Dijk, Rob

1998 Culture as Excuse: The Failures of Health Care to Migrants in the Netherlands. I:

Sjaak van der Geest \& Adri. Rienks (eds.): The Art of Medical Anthropology.

Readings. Amsterdam: Het Spinhuis Publishers.

Wright, Susan

1998 The Politicisation of 'Culture'. Anthropology Today 14(1):7-15. 
